\title{
Kultura szkoły stymulująca kształtowanie uczącej się wspólnoty
}

\section{STRESZCZENIE}

W artykule przedstawiono pojęcie wspólnoty jako kategorii socjologicznej, wskazano na różne sposoby jej definiowania, wyeksponowano znaczenie sentymentów, ładu moralnego, identyfikacji i styczności w jej rozumieniu. Określono wspólnotę uczącą się jako grupę ludzi stykających się ze sobą, mających poczucie więzi, świadomość własnej tożsamości i odrębności, a także doświadczających wzajemnego wsparcia, uznania i przynależności. Wskazano uwarunkowania procesu kształtowania się takiej wspólnoty w szkole i skoncentrowano się na czynnikach związanych ze szkołą. Podkreślono rolę nauczyciela w kreowaniu kultury szkoły sprzyjającej tworzeniu uczącej się wspólnoty. Wyeksponowano wiedzę i umiejętności nauczyciela, jego cechy osobowe i postawę wobec życia, a także motywację nauczyciela do ciągłego uczenia się, autorefleksję i autoewaluację codziennej praktyki. W wyniku analiz stwierdzono, że powstaniu wspólnoty uczącej się w szkole sprzyja kultura współpracy, dialogu i twórczości i jednocześnie taki typ kultury organizacyjnej może kształtować się pod wpływem uczącej się wspólnoty.

\section{Słowa kluczowe:}

kultura organizacyjna, wspólnota, ucząca się wspólnota, rola nauczyciela

1 Agata Cudowska, Wydział Pedagogiki i Psychologii, Uniwersytet w Białymstoku, Polska, a.cudowska@uwb.edu.pl. 


\begin{abstract}
The article presents the concept of community as a sociological category, there are various ways to define it, the importance of sentiment, moral order, identification and contact in its meaning is emphasized. A learning community is identified as a group of people in contact with each other, having a sense of bond, awareness of their own identity and individuality, as well as experiencing mutual support, recognition and belonging. The determinants of the process of shaping such a community in the school are indicated and the focus is on school-related factors. The teacher's role in creating a school culture conducive to creating a learning community is emphasized. The teacher's knowledge and skills, his personal characteristics and attitude to life are emphasized, as well as the teacher's motivation for continuous learning, self-reflection and self-evaluation of everyday practice. As a result of the analysis, it is found that the creation of a learning community at school is fostered by the culture of cooperation, dialogue and creativity, and at the same time this type of organizational culture can be influenced by the learning community.
\end{abstract}

\title{
Keywords:
}

organizational culture, community, learning community, teacher's role

\section{WPROWADZENIE}

Analiza tytułowej problematyki artykułu zakorzeniona jest w kilku dziedzinach i obszarach problemowych, przede wszystkim zaś w pedagogice, socjologii, antropologii kulturowej, naukach o kulturze oraz w teorii organizacji i zarządzania, z których wyprowadzono sens i znaczenie podstawowych kategorii w edukacji. Głównym przedmiotem zainteresowania jest tutaj szkoła, jako wiodąca instytucja oświatowa, w której dokonują się procesy kształcenia i wychowania od wczesnych lat życia. Refleksja koncentruje się zaś na cechach kultury organizacyjnej szkoły, które tworzą optymalne warunki dla uczenia się i sprzyjają powstawaniu wspólnoty ludzi uczących się: nauczycieli, uczniów, rodziców, innych pracowników szkoły i podmiotów środowiska lokalnego zaangażowanych w proces kształcenia. „Wspólnota nie jest tylko tradycyjną i nienowoczesną formą życia, ale jest stałą kategorią psychiki ludzkiej, nie jest w stosunku do jednostki jedynie zespołem więzów krępujących i ograniczających, ale ma również doniosłe znaczenie, pobudzające i harmonizujące osobowość jednostki. Powstaje wówczas poczucie trwałości i ważności pewnego wspólnego typu życia” (Suchodolski, 1936, s. 53). 


\section{SPECYFIKA WSPÓLNOTY I KATEGORIA WSPÓLNOTY UCZĄCEJ SIĘ}

Pojęcie wspólnoty rozumiane jest najczęściej jako swoisty zbiór zasad i norm organizujących relacje między jednostką a społeczeństwem, systemy wartości, postawy, wzory zachowań, typy mentalności i swoiste orientacje życiowe. Nie ma natomiast jakiejś jednej, uznanej przez wszystkich socjologów definicji wspólnoty, wyróżnia się natomiast dwa podstawowe elementy w tej kategorii: styczność oraz identyfikacja. Jedno ujęcie wspólnoty eksponuje przebywanie ludzi na wyraźnie określonym społecznie i politycznie terytorium, na którym realizują oni swoje cele, zaś drugie podkreśla społeczną tożsamość grupy różniącą się zasadniczo od innych grup oraz identyfikację jej członków (Mikołajewska, 1999). Ferdinand Tönnies, który pierwszy dokonał analizy wspólnoty w socjologii, uznał za jej podstawę wspólnotę krwi, tak jak relacja matki i dziecka, ojca czy rodzeństwa. Uważał ją za naturalną jedność urzeczywistniającą się we wspólnocie terytorium, czyli współzamieszkiwaniu i prowadzącą do wspólnego działania w jednym kierunku. Wspólnota krwi i terytorium przekształca się zatem we wspólnotę ducha, która jest swoiście ludzkim, najwyższym rodzajem wspólnoty (Tönnies, 2008).

Pojęcie wspólnoty ewoluuje wraz ze zmianami społecznymi, a rozważania nad jego fenomenem zakorzenione są w krytycznej, konserwatywnej i religijnej myśli społecznej (Mikołajewska, 1999). Czasami było przedmiotem zainteresowania samo w sobie tak jak w XIX-wiecznej socjologii - a innym razem stanowiło narzędzie do badań i wówczas utożsamiano ją ze społecznością lokalną. Wspomniany już Tönnies w 1887 r. opisywał wspólnotę (Gemeinschaft) jako miejsce, w którym panują bliskie relacje międzyludzkie oparte na przypisanym statusie, realizowane są harmonijne role społeczne, a więzi społeczne są głębokie i trwałe (Tönnies, 2008). Wśród cech opisujących pojęcie wspólnoty w różnych definicjach na pierwszym miejscu znajdują się wspólne cele, normy i środki realizacji. W tradycyjnych definicjach wspólnoty eksponuje się interakcje między jednostkami, mające na celu zaspokojenie potrzeb członków wspólnoty i realizację przedsięwzięć grupowych (Mikołajewska, 1999). Wyróżnia się także trzy podstawowe elementy wspólnoty: członka wspólnoty, wspólnotowe grupy oraz fazy i procesy wspólnotowego działania. Natomiast solidarność, wspólne interesy członków i fizyczną naturę środowiska akcentuje się w ekologicznych ujęciach tego fenomenu, charakterystycznych dla przedstawicieli szkoły chicagowskiej. Badanie wspólnot bywa też sposobem na zbieranie ogólnych danych społecznych, często analizuje się je na kontinuum miejskość-wiejskość, a czasami podejmowane są próby zastąpienia niejednoznacznego pojęcia wspólnoty inną kategorią, np. „lokalny system społeczny” (Margaret Stacey) czy „sieć społeczna” (John Barnes) (Mikołajewska, 1999). 
Idea zakorzenienia jednostki w różnego typu wspólnotach i solidarnego działania na rzecz wspólnego dobra stanowi podstawę komunitaryzmu². Współcześnie w pojęciu wspólnoty podkreśla się znaczenie sentymentów i ładu moralnego.

Tworzenie wspólnot przypisuje się potrzebie przezwyciężenia zagrożeń życia człowieka w kulturze indywidualizmu wynikających z rozbicia więzi pierwotnych przez urbanizację, przemysł i stechnicyzowaną cywilizację. Wspólnota służy zaspokojeniu potrzeby sympatii, przynależności, samorealizacji i sensu własnego bytu. Szczególnego znaczenia wspólnoty można upatrywać w wychowaniu, które powinno odpowiadać na zagrożenia powodowane „tempem życia i przerostem ekonomicznego punktu widzenia” (Suchodolski, 1936, s. 67). Bogdan Suchodolski podkreśla również, że „wychowanie moralno-społeczne jest więc zaprawianiem do twórczego uczestnictwa w potoku życia, do współdziałania z innymi i do wydobywania z siebie nieznanych jeszcze w chwili bieżącej możliwości” (Suchodolski, 1936, s. 66). Nadaje to szczególną rangę działaniom rozwijającym twórcze orientacje życiowe podmiotów edukacji w codziennym życiu szkoły. Jest to również niezwykle ważne w kształtowaniu kultury uczenia się i postrzeganiu szkoły jako doskonalącej się organizacji. Wybitny pedagog stwierdził, że twórczość daje nam poczucie siły, działalność jest zorientowana na dobro, a inny jest jej współuczestnikiem, zaś twórcze istnienie umożliwia odczucie pełni życia (Suchodolski, 1936).

Wspólnota ucząca się może być zatem opisywana przez pryzmat kilku wyznaczników istotnych w rozumieniu wspólnoty jako takiej. Możemy w niej wskazać na styczność terytorialną, poczucie więzi między członkami, świadomość własnej tożsamości i odrębności, a także spełnianie przez nią funkcji wspierającej, zaspokajanie potrzeby uznania, przynależności i samorealizacji. Otwarte pozostaje pytanie, na ile możliwe jest (u)kształtowanie takiej wspólnoty w szkole funkcjonującej w warunkach neoliberalnej polityki oświatowej kultury indywidualizmu. Oparta jest ona bowiem na: a) nieskrępowanym wyrażaniu opinii indywidualnych w konfrontacji z opiniami i racjami innych; b) przekonaniu, że własny interes, pragnienia i plany życiowe mają pierwszeństwo przed innymi; c) spotkania stwarzają potrzebę komunikowania słownego, zapełniania ciszy nawet banalną rozmową; d) łamanie norm społecznych rodzi poczucie winy jednostki, ze względu na intensywnie przeżywaną świadomość siebie („kultura winy”); zaś e) osiągnięcie celu (sukcesu) jest ważniejsze niż osobiste relacje. Takie przekonania i zachowania nie

2 Szerzej kwestie te opisałam w: Cudowska, A. (2009). Wspólnota w kulturze indywidualizmu. W: J. Nikitorowicz, J. Muszyńska i M. Sobecki (red.), Wspólnoty z perspektywy edukacji międzykulturowej (s. 198-213). Białystok: Wydawnictwo Uniwersyteckie Trans Humana. 
sprzyjają budowaniu wspólnoty, która wymaga innych warunków. Wydaje się, że możliwości jej rozwoju lokują się bardziej w kulturze kolektywistycznej, w której ludzie są nastawieni na: a) unikanie bezpośredniej konfrontacji i starć z innymi, rzadko używa się słowa „nie”; b) lojalność członków wobec grupy i zobowiązania wobec rodziny; c) współobecność, która nie wymusza konieczności rozmowy, rozmowa wyłania się z potrzeby przekazania informacji; d) poczucie wstydu, które jest zjawiskiem społecznym, zależy od tego, czy o przewinieniu wiedzą inni, jego źródłem nie jest samo złamanie normy, ale jego ujawnienie („kultura wstydu”); e) osobiste relacje są ważniejsze od osiągnięcia celu (Hofstede, 2000).

\section{UWARUNKOWANIA TWORZENIA SIĘ UCZACEJ SIĘ WSPÓLNOTY}

Tworzenie uczącej się wspólnoty w szkole wymaga wielu sprzyjających warunków społecznych i odpowiedniego klimatu politycznego, ale przede wszystkim zależy od ludzi kreujących przestrzeń edukacyjnego dialogu. W szkole powinno dochodzić do spotkania w jego dialogicznym sensie, jako takiego wydarzenia, w którym ludzie świadomie i z zaangażowaniem wchodzą w relację z innym, wspólnie odkrywają sens wartości i rozpoznają siebie jako wartość, wspólnie tworzą nową jakość. Doświadczenie spotkania w edukacji nie jest wcale łatwe, raczej nie zdarza się samoistnie, wymaga celowych działań, troski i starań. Jednak nawet wtedy nie musi dojść do dialogicznego spotkania podmiotów i do przeżycia najgłębszego sensu edukacji, ponieważ spotkanie jest wydarzeniem i nie można go zadekretować (Tischner, 1982; Gadacz, 2002; Walczak, 2007). Sposób myślenia i działania ludzi decyduje o kulturze organizacyjnej instytucji, dlatego właśnie postawy nauczycieli są najbardziej znaczące w procesie kształtowania uczącej się wspólnoty.

Człowiek jako istota społeczna i dialogiczna potrzebuje innych do własnego rozwoju, do urzeczywistniania swojego potencjału. Powstanie wspólnoty ludzi uczących się jest zatem naturalną konsekwencją, ale też koniecznym warunkiem funkcjonowania szkoły jako uczącej się organizacji. W takiej szkole dokonuje się swoista zmiana we wzajemnych relacjach, w organizacji procesów dydaktyczno-wychowawczych, w metodach pracy nauczycieli i sposobach funkcjonowania uczniów. Jest ona możliwa dzięki temu, że wszyscy uczestnicy tych działań mają świadomość celów zmiany i są zaangażowani w jej przebieg, ponieważ podzielają wspólną wizję pracy szkoły i pragną osiągnąć te same efekty. W koncepcji Petera Senge (2002) takie postrzeganie szkoły przez jej pracowników i uczniów umożliwia konstruktywne rozwiązywanie konfliktów i traktowanie zmiany jako procesu 
uczenia się, wzajemnej adaptacji i rozwoju oraz samodoskonalenia formalnych i nieformalnych procedur, norm i struktur. Określa on konieczną zmianę jako „metanoję”, czyli zmianę w sposobie myślenia, która polega na uchwyceniu głębszego znaczenia uczenia się, w którym „organizacja ucząca się nieprzerwanie rozszerza swoje zdolności do kreowania własnej przyszłości” (Senge, 1990, s. 13-14). Wprowadza także pojęcie „mistrzostwa osobistego” jako dyscypliny osobistego rozwoju i uczenia się (Senge, 1998, s. 146), które obejmuje nie tylko kompetencje i umiejętności, ale także przyjęcie twórczego sposobu widzenia świata (Senge, 1998). Jest to zatem spojrzenie zbieżne z moją koncepcją twórczych orientacji życiowych i nadaje szczególną rangę analizowanym przeze mnie preferencjom nauczycieli w tym zakresie (Cudowska, 2014).

Mistrzostwo osobiste jest procesem całożyciowym, wymaga ciągłego określania tego, co jest dla nas naprawdę ważne oraz ciągłego uczenia się wyraźnego dostrzegania otaczającej nas rzeczywistości (Senge, 1998). „Ludzie, którzy osiągnęli wysoki poziom mistrzostwa osobistego, są w pełni świadomi swojej niewiedzy, swej niekompetencji, kierunków, w jakich musi iść ich dalszy konieczny rozwój” (Senge, 1998, s. 148). Z osobistego zaangażowania nauczycieli, uczniów i innych pracowników szkoły wypływa wspólna wizja pracy, misja i podstawowe wartości, które umożliwiają tworzenie uczącej się wspólnoty (Senge, 1998). Naturalną konsekwencją tego procesu, który może być także jego impulsem, jest zespołowe uczenie się, w którym niezbędna jest wspólna wizja, świadomość celu, marzenia oraz mistrzostwo osobiste, w którym wysokie kompetencje wiążą się z uporządkowanym sposobem myślenia, czyli modelami mentalnymi (Senge, Kleiner, Roberts, Ross, Smith, 2008).

Uczenie się zespołowe zachodzi dopiero wtedy, gdy tworzą się mikroświaty stymulujące uczenie się całej organizacji i generowane są informacje, które zostają przetworzone na działania prowadzące do jej profesjonalizacji (Senge, Kleiner, Roberts, Ross, Smith, 2008). Dokonuje się w tym procesie zmiana sposobu myślenia w kierunku ujęcia systemowego, następuje „przejście od postrzegania siebie jako bytu odseparowanego od świata do jedności ze światem, od postrzegania problemów jako powodowanych przez kogoś lub coś innego do spostrzeżenia, że nasze własne działania tworzą problemy, których doświadczamy. Organizacja ucząca się to miejsce, gdzie ludzie odkrywają na nowo, w jaki sposób tworzą otaczającą ich rzeczywistość i jak mogą ją zmieniać. (...) Dzięki uczeniu się jesteśmy w stanie zrobić coś, czego inaczej nie bylibyśmy w stanie zrobić, postrzegamy świat i nasze relacje z nim, rozwijamy nasze możliwości twórcze i stajemy się częścią twórczych procesów życia” (Senge, 1998, s. 25-26). Wspólnota ludzi uczących się nie musi ograniczać się jedynie do szkoły jako instytucji realizującej 
kształcenie formalne, może być tworzona także w innych placówkach oświatowych w środowisku lokalnym lub poza nimi, w ramach nieformalnych grup zrzeszających ludzi na zasadzie dobrowolności. Szkoła jest jednak miejscem szczególnie predestynowanym do tworzenia takiej wspólnoty, w której wszyscy uczestnicy są aktywni, rozumieją wpływ własnego działania na proces uczenia się i na innych, potrafią nim kierować, panują nad swoimi emocjami, wchodzą w częste i wartościowe wzajemne interakcje, uczą się we współpracy, co sprzyja „kształtowaniu kreatywności rozumianej jako proces społeczny, a nie jako ekspresja pojedynczego talentu, geniuszu” (Mazurkiewicz, 2015, s. 22).

\section{KULTURA UCZENIA SIĘ I WSPÓŁPRACY}

W tworzeniu uczącej się wspólnoty bardzo ważna jest, jak to już sygnalizowano, kultura organizacyjna szkoły, na którą składają się zachowania uczniów i pracowników szkoły, przede wszystkim nauczycieli, obowiązujące w niej normy i wartości akceptowane przez wszystkie podmioty edukacyjnego dialogu. Nie ma co prawda jednej, przyjętej przez wszystkich badaczy definicji tej kategorii pojęciowej, ale na potrzeby niniejszych rozważań możemy przyjąć propozycję międzynarodowego eksperta w dziedzinie strategii organizacji i konkurencji Michaela E. Portera (1985, 1992), który określił ją mianem drogowskazu prowadzącego do sukcesu. W definicjach kultury organizacyjnej zwraca się uwagę na sposób działania i myślenia ludzi pracujących w danej instytucji ${ }^{3}$. Kultura organizacyjna szkoły obejmuje szereg elementów takich jak: artefakty, wartości, normy i polityka organizacji, które są ukształtowane przez tradycje i otoczenie. Każda szkoła tworzy własny model kultury organizacyjnej, ponieważ o jej kształcie decydują myśli, odczucia i zachowania ludzi, nauczycieli i uczniów. Na kulturę szkoły składa się: system zarządzania zasobami ludzkimi, który zapewnia identyfikację pracowników z organizacją; system zarządzania jakością, czyli wprowadzenie i egzekwowanie procedur zapewniających profesjonalizację działań; oraz satysfakcjonujące efekty osiągnięte dzięki spełnianiu dwóch pierwszych warunków. Kultura organizacyjna stanowi podstawę sukcesu lub porażki szkoły w realizacji jej misji, ponieważ jednoczy, stabilizuje, zmniejsza niepewność, zapewnia wspólnotowe postrzeganie i zaspokajanie potrzeb. W analizach tego fenomenu akcentuje się także znacze-

3 Szereg definicji kultury organizacyjnej przedstawiam w: Cudowska, A. (2016). Kultura organizacyjna szkoły jako czynnik zmiany oświatowej. W: S. Jaczyński, J. Kunikowski (red.), Kultura bezpieczeństwa. Potrzeby i uwarunkowania, t. 1 (s. 387-406). Siedlce: Wydawnictwo Uniwersytetu Przyrodniczo-Humanistycznego w Siedlcach. 
nie tradycji, międzygeneracyjnego przekazu kulturowego, uznawanego systemu wartości, przyjętych wzorów zachowań, symboli i postaw uczestników szkolnego życia (Bolesta-Kukułka, 2003). Nie mniej istotny w jej kształtowaniu się jest wpływ środowiska, w którym funkcjonuje szkoła oraz dokonania jej dyrektorów. Złożony splot wielorakich czynników wewnętrznych i zewnętrznych powoduje wykształcanie się całego systemu symboli, który umożliwia określoną interpretację rzeczywistości i nadawanie realnego kształtu organizacji (Kieżun, 1998). Można zatem przyjąć, że kultura organizacyjna szkoły stanowi swoisty zbiór dominujących wartości i norm postępowania, który przejawia się poprzez sztuczne twory danej kultury, czyli artefakty (Kostera, 2004). Są one zauważalne przy pierwszym zetknięciu się z daną placówką i można wyróżnić wśród nich: a) artefakty językowe przejawiające się w specyficznym języku organizacji, jak też w mitach o jej założycielu i pracownikach; b) artefakty behawioralne, czyli ceremonie, rytuały, np. związane z przyjęciem nowych pracowników lub spotkaniami pracowników z okazji świąt; a także c) artefakty fizyczne, takie jak flagi, logo czy kolory.

Kultura organizacyjna szkoły pełni szereg ważnych funkcji, które są niezbędne w procesie kształtowania uczącej się wspólnoty. Integruje uczestników działań edukacyjnych, koncentruje się na zachowaniu organizacji w całości, dostarcza informacji na temat zasad obowiązujących w szkole, umożliwia nabywanie umiejętności zachowania się wymaganego w danej placówce, ukazuje gotowe, utarte wzory zachowywania się w różnych sytuacjach, co prowadzi do zmniejszenia niepewności, wspomaga rozwijanie zdolności radzenia sobie z problemami zewnętrznej adaptacji i wewnętrznej integracji, a także zwiększa zaangażowanie pracowników w sprawne działanie szkoły (Gitling, 2013). Kultura szkoły w znacznej mierze determinuje możliwość zmiany oświatowej rozumianej jako doskonalenie edukacji. Jej wyrazem są wartości oparte na wierze, kodeksie etycznym oraz intuicji moralnej, postrzegane w kontekście norm społecznych, obyczajów, oczekiwań i standardów akceptowanych społecznie. Wartości te doświadczane są przez uczestników szkolnej edukacji jako preferencje i odczucia osobiste, mają charakter emocjonalny i behawiorystyczny (Hildebrand, 2001).

Kultura organizacyjna współczesnej szkoły zależy od bardzo wielu czynników mieszczących się w samej szkole, jak i poza nią, w środowisku lokalnym. Mają na nią wpływ przemiany w dziedzinie zarządzania edukacją dokonujące się w wymiarze regionalnym i globalnym, takie jak: decentralizacja procesów decyzyjnych w oświacie, zwiększenie niezależności ekonomicznej przez organy administracji lokalnej i poszczególne placówki, rynkowy model zarządzania szkołami i jego uspołecznienie prowadzące do powstania organów konsultacyjnych na szczeblu centralnym, regionalnym i pojedynczych szkół (Śliwerski, 2013), wzrost auto- 
nomii szkół (Rabczuk, 2007; Váňová, 2006). Przy czym decydujący dla procesu budowania kultury szkoły sprzyjającej tworzeniu uczącej się wspólnoty jest rozwój profesjonalny nauczycieli, na co wskazują badacze tej problematyki (Dalin, Rust, 1983; Dalin, Rolff, 1993; Fullan, 2007; Senge, 1998). Ludzie tworzący daną organizację mają bowiem największy wpływ na jej kulturę, gdyż w codziennej pracy, w sposobie realizacji zadań, rozwiązywania problemów i wypełniania funkcji charakterystycznych dla ich roli zawodowej tworzą określony klimat funkcjonowania szkoły. Od tego, czy tworzą zespół, czy są tylko zbiorem jednostek nie współpracujących ze sobą, zależy powodzenie w osiąganiu celów.

\section{NAUCZYCIEL JAKO KREATOR WSPÓLNOTY UCZĄCEJ SIĘ}

Oczywiście nie umniejsza to znaczenia kontekstu politycznego, ekonomicznego, społecznego i kulturowego, w którym zanurzona jest każda organizacja i który określa pewne ogólne ramy jej funkcjonowania. Doceniając jego rangę, pozostaniemy jednak przy analizach roli nauczyciela jako głównego kreatora zmiany oświatowej i kształtowania uczącej się wspólnoty. Eksponuje ją w swojej koncepcji Michael Fullan (2007), który wskazuje na sposób, w jaki ludzie doświadczają zmiany. Rozumienie sensu określonych zmian w funkcjonowaniu szkoły i podzielanie ich sensu przez edukatorów uznaje za fundamentalny czynnik w tworzeniu nowej jakości. Nawet najbardziej wartościowa propozycja doskonalenia pracy szkoły, a za taką należy uznać budowanie w niej wspólnoty ludzi uczących się razem, nie będzie mogła się urzeczywistnić, jeśli nie zaakceptują jej nauczyciele. Dopiero zinternalizowanie przez nich wartości uczącej się wspólnoty otwiera drogę do tworzenia jej w szkole. Propozycja taka nie może być narzucona z zewnątrz, ponieważ najprawdopodobniej wywoła opór i niechęć pracowników szkoły i tak przeciążonych nadmiarem obowiązków administracyjnych, spowoduje więc ich niechęć i wywoła potrzebę zminimalizowania jej znaczenia. Uświadomienie sobie przez nauczycieli walorów uczącej się wspólnoty może natomiast stymulować ich do podejmowania wysiłków na rzecz tworzenia jej we własnym środowisku. Edukatorzy występują wtedy jako inicjatorzy i eksperci takiej zmiany, która umożliwia wspólne uczenie się, rozwiązywanie problemów i osiąganie nowych wartości, niemożliwych do urzeczywistnienia nawet przez najlepiej pracującego nauczyciela.

W tym procesie uświadamiania, inicjowania i realizowania idei uczącej się wspólnoty szczególne znaczenie mają kompetencje osobowościowe nauczyciela, do których należy: tworzenie własnych wizji pracy w szkole, zinternalizowanie norm, nawyków i technik ustawicznego uczenia się, mistrzostwo osobiste, które 
nie ogranicza się do określonych umiejętności i kompetencji, ale oznacza właśnie twórcze podejście do życia, oraz współpraca z uczniami, dyrekcją, rodzicami, administracją oświatową, przedstawicielami społeczności lokalnej (Fullan, 2007), a także twórcze preferencje w zakresie orientacji życiowych, które obejmują również kreatywność profesjonalną nauczyciela (Cudowska, 2014). Podzielanie przez wszystkich nauczycieli i dyrekcję rozumienia, sensu i sposobu realizacji działań służących budowania uczącej się wspólnoty jest niezbędne do jej urzeczywistnienia w szkole. Taka szkoła staje się tym samym organizacją uczącą się i doskonalącą się zarazem w codziennej pracy, w której zakorzenia się kultura współpracy, dialogu i twórczości. Nie są zatem potrzebne wielkie, kosztowne i obciążające społecznie reformy oświaty, najczęściej nieskuteczne, bo narzucone szkole z zewnątrz przez administratorów i technokratów.

Kultura współpracy i dialogu charakteryzuje się spontanicznością, dobrowolnością, ale także pewną nieprzewidywalnością (Gołębniak, 2004). Jest bowiem tworzona przez samych nauczycieli, wynika z ich potrzeb, daje im satysfakcję, sprzyja rozwijaniu własnej inicjatywy, ustalaniu i realizacji wspólnych zadań. Opiera się na zrozumieniu i podzielaniu wspólnych wartości przez zespół nauczycieli, dyrektora, uczniów i rodziców. Współpraca odbywa się nie tylko w celowo zaplanowanych sytuacjach, ale także w czasie nieformalnych spotkań, nawet przelotnych, jej istotą jest stałość i naturalność. W takiej szkole panują przyjazne, życzliwe relacje między pracownikami, troska o wzajemne zrozumienie i poszanowanie opinii innych. Kształtowaniu kultury współpracy i uczącej się wspólnoty sprzyjają preferencje nauczycieli dla twórczych orientacji życiowych (Cudowska, 2014). Mają oni bowiem silniejsze niż nauczyciele o preferencjach zachowawczych poczucie sprawstwa i odpowiedzialności za doskonalenie pracy szkoły. Świadomie inwestują w swój rozwój profesjonalny i ustawiczny proces uczenia się, cechują się otwartością na drugiego człowieka i na zmianę, gotowością wchodzenia w dialogiczne relacje ze światem, zaangażowaniem i odpowiedzialnością w realizacji zadań, poszukiwaniem nowych, lepszych rozwiązań sytuacji trudnych (Cudowska, 2016).

\section{PODSUMOWANIE}

Kształtowaniu wspólnoty ludzi uczących się sprzyja zaufanie i otwartość partnerów relacji dialogicznej, poczucie odpowiedzialności nauczycieli za wyniki uczenia się swoich uczniów, a także stała współpraca nauczycieli, uczniów, rodziców i społeczności lokalnej. Niezbędne w tym procesie jest również wspólne ustalanie celów, 
zadań i procedur ich realizacji na rzecz dobra całej społeczności (Kwieciński, 2000). Partnerskie relacje i działania zespołowe sprzyjają rozwijaniu u uczniów i nauczycieli postawy badawczej, refleksyjności i dialogowej strategii kształcenia. Współpraca całej społeczności szkolnej, szczególnie w procesie uczenia się w zespołach i na poziomie całej organizacji, jest jednym z podstawowych założeń koncepcji rozwoju organizacyjnego szkoły (Dalin, Rust, 1983), której celem jest pomoc instytucjom w zdiagnozowaniu ich obecnej sytuacji, zaplanowanie zmiany, jej wdrożenie i ewaluację. Tworzenie wspólnoty uczącej się jest procesem niezwykle złożonym, uwarunkowanym wieloma czynnikami bezpośrednio związanymi ze szkołą, a także takimi, które od niej nie zależą. W niniejszych rozważaniach wyeksponowano wiodącą rolę nauczyciela w tym procesie, jako że z wielu międzynarodowych badań wynika, iż jest on głównym motorem, ale i hamulcowym zmian w edukacji. Dzisiaj, bardziej niż kiedykolwiek w historii, profesjonalizm nauczyciela wyraża się nie tylko jego wiedzą i umiejętnościami zawodowymi związanymi z nauczanym przedmiotem, ale przede wszystkim określonymi cechami osobowymi i postawą wobec życia, z której wynika także jego stosunek do pracy. Niezwykle ważna jest motywacja nauczyciela do ciągłego uczenia się jako wartości i naturalnego nawyku, która konstruuje tożsamość nauczyciela. W nią wpisana powinna być również autorefleksja i autoewaluacja codziennej praktyki, dążenie do upełnomocnienia uczniów, ale także „świadomość więzi między celem moralnym na poziomie szkoły i kwestiami polityki oświatowej oraz rozwoju społecznego, musi istotnie pogłębić swoją wiedzę pedagogiczną, musi pracować w sposób interaktywny i kooperujący” (Potulicka, 2001, s. 39).

Wspólnota ludzi uczących się może rozwijać się w określonym środowisku, czyli w odpowiedniej kulturze szkoły, która oparta jest na współpracy, dialogu, twórczości organizacyjnej i kreatywności podmiotów edukacji. Jest ona niewątpliwie warunkiem rozwoju szkoły jako organizacji, ale może być także efektem spontanicznych działań na rzecz tworzenia uczącej się wspólnoty. Współdziałanie nauczycieli w codziennej pracy, wchodzenie w złożone sieci wzajemnych relacji, wsparcie i pomoc w rozwiązywaniu problemów, zespołowe działania i satysfakcja z ich rezultatów mogą być impulsem inicjującym proces zmiany kultury szkoły ze zrutynizowanej na twórczą, z kostycznej, sformalizowanej na swobodną i przyjazną sprzyjającą uczeniu się, a nie tylko prowadzeniu lekcji. 


\section{Bibliografia}

Bolesta-Kukułka, K. (2003). Decyzje menedżerskie. Warszawa: Państwowe Wydawnictwo Ekonomiczne.

Cudowska, A. (2004). Kształtowanie twórczych orientacji życiowych w procesie edukacji. Białystok: Trans Humana.

Cudowska, A. (2009). Twórcze orientacje życiowe nauczycieli. W: Edukacja. Studia. Badania. Innowacje, 3 (107), s. 47-55.

Cudowska, A. (2014). Twórcze orientacje życiowe w dialogu edukacyjnym. Studium teoretyczno-empiryczne. Białystok: Trans Humana.

Cudowska, A. (2016). Kultura organizacyjna szkoły jako czynnik zmiany oświatowej. W: S. Jaczyński, J. Kunikowski (red.), Kultura bezpieczeństwa. Potrzeby i uwarunkowania, t. 1 (s. 387-406). Siedlce: Wydawnictwo Uniwersytetu Przyrodniczo-Humanistycznego w Siedlcach.

Dalin, P., Rolff, H.G. (1993). Changing the School Culture. London: Cassell.

Dalin, P., Rust, V. (1983). Can Schools Learn?. Windsor: NFER-NELSON.

Fullan, M. (2007). The New Meaning of Educational Change. New York and London: Teachers College Press and Columbia University.

Gadacz, T. (2002). O umiejętności życia. Kraków: Wydawnictwo „Znak”.

Gitling, M. (2013). Człowiek w organizacji, ludzie - struktury - organizacje. Warszawa: Difin.

Gołębniak, B.D. (2004). Szkoła wspomagająca rozwój. W: Z. Kwieciński, B. Śliwerski (red.), Pedagogika. Podręcznik akademicki, t. 2 (s. 96-157). Warszawa: PWN.

Hildebrandt, A. (2001). Koncepcja rozwoju organizacyjnego szkoły Pera Dalina. W: E. Potulicka (red.), Szkice z teorii i praktyki zmiany oświatowej (s. 61-138). Poznań: Wydawnictwo Eruditus.

Hofstede, G. (2000). Kultury i organizacje. Przeł. M. Durska. Warszawa: Polskie Wydawnictwo Ekonomiczne.

Kieżun, W.J. (1998). Sprawne zarzq̨dzanie organizacją: zarys teorii i praktyki. Warszawa: Oficyna Wydawnicza Szkoły Głównej Handlowej.

Kostera, M.M. (2004). Zarządzanie międzykulturowe. W: A.K. Koźmiński, W. Piotrowski (red.), Zarzqdzanie: teoria i praktyka (s. 583-614). Warszawa: PWN.

Kwieciński, Z. (2000). Tropy - ślady - próby. Studia i szkice z pedagogii pogranicza. Poznań-Olsztyn: Edytor.

Mazurkiewicz, G. (2015). Teoria ewolucji. Od uczących się jednostek do uczącej się wspólnoty. W: G. Mazurkiewicz (red.), Uczq̨ca się szkoła. Od rozwoju jednostek do rozwoju wspólnoty (s. 13-24). Warszawa-Kraków: Wydawnictwo Uniwersytetu Jagiellońskiego.

Mikołajewska, B. (1999). Zjawisko wspólnoty. New Haven: The Lintons`Video Press.

Porter, M.E. (1985). Competitive advantage: creating and sustaining superior performance. New York-Toronto: The Free Press.

Porter, M. E. (1992). Strategia konkurencji: metody analizy sektorów i konkurentów. Przeł. A. Ehrlich. Warszawa: PWE.

Potulicka, E. (2001). Paradygmat zmiany edukacyjnej Michaela Fullana. W: E. Potulicka 
(red.), Szkice z teorii i praktyki zmiany oświatowej (s. 11-60). Poznań: Wydawnictwo Eruditus.

Rabczuk, W. (2007). Polityka edukacyjna Unii Europejskiej: nowe konteksty. Warszawa: Wydawnictwo WSP TWP.

Senge, P.M. (1990). The Fifth Discipline: The Art and Practice of the Learning Organisation. New York: Currency Doubleday.

Senge, P.M. (1998). Piq̨a dyscyplina. Teoria i praktyka organizacji uczq̨cych się. Przeł. H. Korolewska-Mróz. Warszawa: Dom Wydawniczy ABC.

Senge, P.M., Kleiner, A., Roberts, Ch., Ross, R.B., Smith, B.J. (2008). Piq̨ta dyscyplina. Materiały dla praktyka: jak budować organizację uczq̨cq się. Przeł. G. Łuczkiewicz. Kraków: Wolters Kluwer Business.

Suchodolski B. (1936). Wychowanie moralno-społeczne. Warszawa: Nasza Księgarnia Spółka Akcyjna Związku Nauczycielstwa Polskiego.

Śliwerski, B. (2013). Diagnoza uspołecznienia publicznego szkolnictwa III RP w gorsecie centralizmu. Kraków: Oficyna Wydawnicza Impuls.

Tönnies, F. (2008). Wspólnota i stowarzyszenie: rozprawa o komunizmie i socjalizmie jako empirycznych formach kultury. Przeł. M. Łukasiewicz. Wstęp do wyd. polskiego J. Szacki. Warszawa: PWN.

Váňová, M. (2006). Pedagogika porównawcza. W: B. Śliwerski (red.), Pedagogika, t. 2, Pedagogika wobec edukacji, polityki oświatowej i badań naukowych (s. 49-105). Gdańsk: GWP.

Walczak, P. (2007). Wychowanie jako spotkanie. Józefa Tischnera filozofia człowieka jako źródło inspiracji pedagogicznych. Kraków: Oficyna Wydawnicza Impuls.

Tischner, J. (1982). Myślenie według wartości. Kraków: Wydawnictwo „Znak”. 